\title{
Multi-factor Models after the Financial Crisis - An empirical analysis for the German stock market
}

Peter Hennecke ( $\sim$ peter.hennecke@fom-net.de)

FOM University of Applied Sciences - Hamburg Campus: FOM - Standort Hamburg

Ragnar Jessen

unaffiliated

Mihail Topalov

FOM University of Applied Sciences - Hamburg Campus: FOM - Standort Hamburg

Research Article

Keywords:

Posted Date: January 31st, 2022

DOI: https://doi.org/10.21203/rs.3.rs-1187898/v1

License: (1) This work is licensed under a Creative Commons Attribution 4.0 International License.

Read Full License 


\section{Introduction}

Capital market research has generated an abundance of works on the topic of factor models. The paper by Fama and French, published in 1993, has been attributed a central role for this research area. Motivated by the lack of empirical evidence of the CAPM at the time, the two economists explored whether an expansion of the CAPM could significantly increase the explanatory contribution of American stock returns. Their main interests were the two risk factors of the firm size in the form of market capitalization and the fundamental value, represented by the book-market-ratio. The promising results of their work attested the presented three-factor model strong empirical explanatory power. A strong influence on the excess returns of American securities became apparent for all three risk factors. However, the model could not withstand the requirements of an equilibrium model.

Hence, in the following years increased efforts were made to identify further risk factors and to transfer them into new factor-models. One of the models, which also received a lot of attention, is Carhart's 1997 four-factor model which complements the model by Fama and French (1993) and the momentum-factor. Both models have been reexamined and confirmed at international level many times since their publication. In the context of this analysis, the status of research regarding the German stock market after the financial crisis shall be updated based on the most recent stock market data. In order to do so, the aforementioned models will be examined with regard to their explanatory power, the influence and significance of individual risk factors, as well as their eligibility as an equilibrium model.

\section{Multi-factor Models}

The development of factor models is primarily based on the results of the capital market equilibrium model developed by Sharpe (1964), Lintner (1965) and Mossin (1966), the Capital Asset Pricing Model (CAPM). This model is supposed to facilitate the valuation of securities in the market equilibrium. In this context, the market risk premium $\left[E\left(r_{m}\right)-r_{f}\right]$ is of central importance, which constitutes compensation for the acquisition of systematic risks of investors. The beta factor $\beta_{i}$ describes how a single security behaves in comparison with a perfectly diversified market portfolio. In the market equilibrium, all securities can be found on the security line described by the CAPM in the long run (Sharpe 1964, p. 437-438; Zimmermann 2006, p. 174).

$$
E\left(r_{i}\right)=r_{f}+\beta_{i}\left[E\left(r_{m}\right)-r_{f}\right]
$$


According to neoclassical theory, security returns in the market equilibrium cannot permanently deviate from the security line. As early as in the late 1970s, however, security-specific characteristics were discovered which did not meet these requirements and hence questioned the validity of the CAPM. Studies on the so-called 'size-effect" demonstrated a systematic deviation of the expected returns of the CAPM for companies with a low market capitalization over a longer period of time. Works on the 'value-effect' showed similar results. Here, companies with a high book-market-ratio (BE/ME) showed an excess return compared to those with a smaller fundamental value (Black et al. 1972; Banz 1981; Reinganum 1981; Rosenberg et al. 1985; Breeden et al. 1989; Fama and French 2004).

Based on the findings of the Arbitrage Pricing Theory by Ross (1976), in the early 1990s, Fama and French developed a multi-factor model which henceforth enabled the valuation of security returns on the basis of three risk factors. Contrary to the CAPM, however, it is not an equilibrium model but an empirical index model, which establishes the interconnection of a security's index and its returns. For the analysis and prognosis of excess returns, one can resort to the statistical method of linear regression. The obtained data can help determine the influence of individual variables on the excess returns. However, the data does not explain the causal relationship between the dependent and independent variables. The CAPM-compatible singlefactor model is the basis of the multi-factor models discussed in this paper. It builds on the market model of the CAPM and consists of the following components:

$$
r_{i t}-r_{f t}=\alpha_{i}+\beta_{i}\left[r_{m t}-r_{f t}\right]+\varepsilon_{i t}
$$

The difference resulting from the returns of a security or portfolio and the risk-free interest rate $r_{i t}-r_{f t}$ represents the dependent variable of the regression model, whereas the market risk premium $\left[r_{m t}-r_{f t}\right]$ constitutes the independent variable of the model. $\beta_{i}$ describes the security's behavior in comparison with the market risk premium. $\alpha_{i}$ represents the share of returns which cannot be explained by systematic risks. $\varepsilon_{i}$ is the residue and corresponds with the observed scatter which cannot be explained by the regression model. Taken together, $\alpha_{i}$ and the error term $\varepsilon_{i}$ represent the company-specific risk. Since the security return in the market equilibrium cannot permanently deviate from the security line, their estimated value equates to zero (Mondello 2015, p. 201-202; Ziegler et al. 2007, p. 360; Black et al. 1972, p. 44-45). 


\section{Three-factor Model}

In 1992, the capital market researchers Fama and French examined anomalies of the capital market, which, in combination with the known market risk premium, might increase the explanatory power of security returns. Among other aspects, the focus of their work was on the book-market-ratio (BE/ME) and the company size, as measured by the market capitalization (ME).

Some years later, in 1995, Fama and French explored the causes of the development of the two market anomalies. One explanatory attempt of the two economists focused on the low profitability of companies. According to them, particularly companies of small size or those with a high $\mathrm{BE} / \mathrm{ME}$ were confronted with this challenge. Investors would demand a compensation in form of a risk premium for the high contingency risk of the securities (Fama and French 1995, p. 153-154). Further explanatory attempts were based on psychological behavioral patterns, which were analyzed in the context of Behavioral Finance.

According to these theories, anomalies can occur due to the irrationality of the market participants. For instance, investors could overestimate the growth prospects of a company relative to the concomitant risk or measure, or they might measure their return expectations disproportionately to the historical profit development (Zimmermann 2006, p. 270-271).

In 1993, Fama and French transferred the two anomalies into the one-factor model, which gave way to the three-factor model. With the help of multiple time series regressions, the authors were able to demonstrate that the examined risk factors had a significant influence on the excess returns of the American stock market and that the empirical model was more suitable to explain the cross section of average stock returns between 1963 and 1990 than the traditional single-factor model (Fama und French 1993, p. 4).

$$
r_{i t}-r_{f t}=\alpha_{i}+\beta_{i 1}\left[r_{m t}-r_{f t}\right]+\beta_{i 2} S M B_{t}+\beta_{i 3} H M L_{t}+\varepsilon_{i t}
$$

$r_{i t}-r_{f t}$ and $\left[r_{m t}-r_{f t}\right]$ correspond to the specifications of the CAPM. SMB $B_{t}$ (Small minus Big) is the second risk factor and represents the company size ME. The third factor, $H M L_{t}$ (High minus Low), describes the ratio between book value and market value, BE/ME. Taken together, these three risk factors took on the role of the independent variables. $\alpha_{i}$ and $\beta_{i 1-3}$ are the coefficients of the regression model which have to be estimated. $\varepsilon_{i}$ constitutes the residue. 


\section{Four-factor Model}

In 1993, Jegadeesh and Titman examined different investment strategies at the capital market, among others the so-called 'momentum-strategy'. The results of their study indicated that the acquisition of 'past winner stocks', and the simultaneous sale of 'past loser stocks' goes along with a disproportionate rate of return (Jegadeesh und Titman 1993, p. 89-90).

Jagadeesh and Titman found one possible behavioral explanatory approach of this anomaly to be the fact that it takes investors some time to realize the positive developments of a security and that they thus increase their expectations gradually after the ensued investment. Hence, an undervaluation of short-term perspectives and an overvaluation of long-term ones occurs. ${ }^{8}$ Four years later, Mark M. Carhart (1997) drew back on these findings and complemented the threefactor model by Fama and French (1993) with a fourth risk factor.

$$
r_{i t}-r_{f t}=\alpha_{i}+\beta_{i 1}\left[r_{m t}-r_{f t}\right]+\beta_{i 2} S M B_{t}+\beta_{i 3} H M L_{t}+\beta_{i 4} W M L_{t}+\varepsilon_{i t}
$$

Carhart's model (1997) shows the same specifications as the three-factor model. The fourth factor, $W M L_{t}$ (Winner minus Loser) represents the returns of former winner stock minus the return of former loser stocks. With $\beta_{i 4}$ the estimation of a regression coefficient takes place for this factor, too.

\section{Data Basis}

The American stock market provides an attractive data basis for the capital market research. A long time series and the size of the market form a robust statistical fundament. In order to sufficiently verify the universality and the explanatory power of empirical studies, it is useful to also focus on other markets and time periods. The data model introduced in this paper shall help update the status of research on multi-factor models at the German stock market after the financial crisis, between 2007 and 2009.

\subsection{Determining Risk Factors}

For the analysis of factor models, a scientific standard based on the work by Fama and French (1993) was established. The present study also follows their methodological approach regarding the construction of the risk factors $S M B_{t}$ and $H M L_{t}$ as well as for the two-dimensionally assorted surplus portfolios. The same holds true for Carhart's risk factor $W M L_{t}$ (1997) and onedimensionally assorted surplus portfolios. 
For the purpose of this paper, CDAX represents the market portfolio $r_{m t}$. EURIBOR's onemonth money serves as the risk-free interest rate $r_{f t}$. Fama and French (1993) suggest using the market capitalization (ME) of a security as a proxy. This factor is being determined by June $30^{\text {th }}$ of each year $t$ from the freely circulating amount of shares and the valid closing price at the closing date. The net asset value is represented by the equity's book-market-ratio (BE/ME) in December of year $t-1$ (Fama and French 1993, p. 8).

The construction of the risk factors $S M B_{t}$ and $H M L_{t}$ is based on six share portfolios. Every June, the securities are classified according to their market value on the basis of the Size and $\mathrm{BE} / \mathrm{ME}$ criteria. The median of the market capitalization separates the data set into small and big companies. The decile of $30 \%$ and $70 \%$ serves as a limit for the classification of the BE/ME data according to the size categories small (low), medium, and high (Fama and French 1993, p. 9).

Table 1: Share Portfolios for the Construction of Risk Factors SMB and HML

\begin{tabular}{|c|c|c|c|c|}
\hline & & & $\mathbf{I} / \mathbf{M}$ & \\
\hline & & Low & & High \\
\hline & Small & S-L & S-M & S-H \\
\hline & Big & B-L & B-M & B-H \\
\hline
\end{tabular}

The construction of the risk factors takes place after the classification is completed. $S M B_{t}$ corresponds with the difference resulting from the average returns of small (S-H, S-M and SL) as well as big companies (B-H, B-M and B-L). The subtraction of the portfolio's medium returns with a high $\mathrm{BE} / \mathrm{ME}(\mathrm{S}-\mathrm{H}$ and $\mathrm{B}-\mathrm{H})$ minus the returns of the portfolios with a low $\mathrm{BE} / \mathrm{ME}$ (S-L and B-L) amounts to the factor $H M L_{t}$ (Carhart 1997, p. 61).

$$
\begin{gathered}
S M B_{t}=\frac{r_{t}^{S-H}+r_{t}^{S-M}+r_{t}^{S-L}{ }_{t}-\frac{r_{t}^{B-H}+r^{B-M}{ }_{t}+r^{B-L} t}{3}}{3} \\
H M L_{t}=\frac{r^{S-H}+r^{B-H} t}{2}-\frac{r^{S-L}+r^{B-L}{ }_{t}}{2}
\end{gathered}
$$

$W M L_{t}$ (,Winner minus Loser") is the fourth factor of the model. This factor is determined by the difference resulting from the average returns of an equally weighted winner and loser portfolio. Contrary to the risk factors by Fama and French (1993), the classification of the securities 
is carried out monthly, based on the performance of the previous 11 months. The winner portfolio comprises $30 \%$ of the companies with the best performance. The loser portfolio comprises $30 \%$ of the securities with the worst growth rate (Carhart 1997, p. 61).

$$
W M L_{t}=\text { Winner }_{t-11}-\text { Loser }_{t-11}
$$

\subsection{Construction of the Test Portfolios}

In order to sufficiently test the factor models analyzed here for the German stock market, an analysis of the 144 monthly excess returns will be conducted for both one-dimensionally and two-dimensionally assorted portfolios. The factors Size, BE/ME, and WML constitute the central sorting criteria, resulting in three one- and two-dimensionally assorted panels. The classification of the Size and BE/ME portfolios is carried out each year by June $30^{\text {th }}$. The classification of the WML portfolios is carried out on a monthly basis.

Since the German capital market is a lot smaller than the American one, the amount of twodimensionally assorted portfolios, contrary to Fama and French (1993), is limited to 16 instead of 25 . The classification of securities is oriented towards the $25 \%, 50 \%$, and $75 \%$ quartile of the respective sorting criteria by June $30^{\text {th }}$. This procedure ensures enough stocks in every portfolio. Based on Carhart (1997), the amount of one-dimensionally assorted portfolios is kept at 10 for each one. The classification is conducted on the basis of the $10 \%$ decile. In order to test the one-, two-, three-, and four-factor model, 234 regressions in total are conducted for the six panels.

\subsection{Conception of the Data Set}

This study is based on all German stocks whose issuers were listed in CDAX between July $1^{\text {st }}, 2008$ and June $30^{\text {th }}, 2020$. The performance index was published in 1993 and mirrors the performance of German companies which officially belong to the general and prime standard.

In order to produce statistically significant results, some adjustments had to be made first. Banks and insurances were excluded from the study as their accounting standards differ from those of other companies (Viale et al. 2009, p. 472). The so-called „Penny-Stocks “, stock companies which simultaneously have a market capitalization of less than 5 million Euros (mEUR) and a closing price of less than 1 Euro, were also excluded (Stehle und Schmidt 2015, p. 9). Moreover, companies with a negative book value of the capital resources were taken out. Finally, the highest and lowest $0.25 \%$ of the return observations were eliminated in order to be able to face the statistical problems of rogue results (Artmann et al. 2012, p. 25). 
Table 2 summarizes the descriptive statistic of the evaluated data set according to which the amount of listed securities increased continually from 226 to 337 between 2007 and 2020. The average market value of the companies ranged between 2,712 mEUR and 5,522 mEUR. The BE/ME developed positively between 2007 and 2019 from 0.65 to 0.92 . For more than $50 \%$ of the companies, the market value of the capital resources was above their book value.

Table 2: Descriptive Statistic of the Evaluated Data Set

\begin{tabular}{|c|c|c|c|c|c|c|c|c|c|}
\hline \multirow[b]{2}{*}{ Year } & \multirow[b]{2}{*}{$\begin{array}{l}\text { Quan- } \\
\text { tity }\end{array}$} & \multicolumn{4}{|c|}{ Size in mEUR } & \multicolumn{4}{|c|}{$\mathrm{BE} / \mathrm{ME}$} \\
\hline & & $\begin{array}{r}\text { Aver- } \\
\text { age }\end{array}$ & Median & $\begin{array}{r}25 \% \\
\text { Decile }\end{array}$ & $\begin{array}{r}75 \% \\
\text { Decile }\end{array}$ & $\begin{array}{l}\text { Aver- } \\
\text { age }\end{array}$ & Median & $\begin{array}{r}25 \% \\
\text { Decile }\end{array}$ & $\begin{array}{r}75 \% \\
\text { Decile }\end{array}$ \\
\hline 2007 & 226 & 4,101 & 274 & 60 & 1,582 & 0.65 & 0.55 & 0.33 & 0.82 \\
\hline 2008 & 240 & 3,182 & 180 & 45 & 1,063 & 1.32 & 0.98 & 0.55 & 1.70 \\
\hline 2009 & 245 & 2,712 & 127 & 36 & 813 & 1.02 & 0.76 & 0.44 & 1.15 \\
\hline 2010 & 258 & 3,073 & 194 & 43 & 1,005 & 1.00 & 0.63 & 0.37 & 0.93 \\
\hline 2011 & 260 & 3,971 & 289 & 54 & 1,445 & 0.99 & 0.80 & 0.49 & 1.14 \\
\hline 2012 & 263 & 3,424 & 229 & 48 & 1,387 & 0.85 & 0.68 & 0.44 & 0.96 \\
\hline 2013 & 269 & 4,115 & 292 & 53 & 1,649 & 0.86 & 0.56 & 0.35 & 0.90 \\
\hline 2014 & 277 & 5,085 & 376 & 87 & 1,909 & 0.91 & 0.58 & 0.36 & 0.87 \\
\hline 2015 & 288 & 5,522 & 357 & 95 & 2,126 & 0.84 & 0.52 & 0.30 & 0.83 \\
\hline 2016 & 300 & 4,623 & 421 & 89 & 2,292 & 0.94 & 0.51 & 0.30 & 0.84 \\
\hline 2017 & 311 & 5,515 & 548 & 109 & 3,153 & 0.76 & 0.41 & 0.23 & 0.76 \\
\hline 2018 & 332 & 5,333 & 487 & 124 & 2,928 & 1.16 & 0.61 & 0.33 & 0.92 \\
\hline 2019 & 329 & 5,066 & 494 & 109 & 2,991 & 0.92 & 0.55 & 0.29 & 0.93 \\
\hline 2020 & 337 & 4,959 & 440 & 80 & 2,825 & & & & \\
\hline
\end{tabular}

Descriptive statistic of the evaluated data set between July 1st, 2007 and June 30th, 2020. The amount of titles and Size were determined by the closing date. The calculation of the BE/ME was conducted by December $31^{\text {st }}$.

\section{Descriptive Statistics}

In the following, risk factors as well as one- and two-dimensionally assorted portfolios will be presented and analyzed in the context of descriptive statistics. The evaluation period covered 144 months, from July $1^{\text {st }}, 2008$ until June $30^{\text {th }}, 2020$.

Table 3 summarizes the measures and correlation matrix of the independent variables. The monthly return of the market portfolio amounted to $0.63 \%$, which equates an average yearly CDAX increase of about $7.56 \%$. Deducing the risk-free interest rate, the average market risk premium $\left[r_{m t}-r_{f t}\right]$ amounts to $0.33 \%$ per month. Other studies on the German stock market produced results between $0.27 \%$ and $0.40 \%$. For the US market, a risk premium in the range 
between $0.43 \%$ and $0.47 \%$ was attested (Ziegler et al. 2007, p. 371; Artmann et al. 2012, p. 27; Fama und French 1993, p. 13-14; Carhart 1997, p. 62).

The second risk factor, $S M B_{t}$, has a median value of $0.36 \%$, thus lining up with the results from the US market of between $0.27 \%$ and $0.29 \%$. A premium in the range between $-0.18 \%$ and $0.08 \%$ was identified for the German stock market. A median risk premium of $0.17 \%$ was attested for the third factor $H M L_{t}$ between 2008 and 2020. The premium thus lies below the results of previous German works, the results of which ranged between $0.40 \%$ and $0.49 \%$. With a monthly return of $0.73 \%$, the highest capital growth can be ascribed to the fourth factor, $W M L_{t}$. In past works, a premium of $0.90 \%$ was identified by Artmann et al. (2012) while Carhart ascertained a risk premium of $0.82 \%$ for the American stock market (Ziegler et al. 2007, p. 371; Artmann et al. 2012, p. 27; Fama und French 1993, p. 13-14; Carhart 1997, p. 62).

\section{Table 3: Measures and Correlation Matrix of Independent Variables}

\begin{tabular}{|c|c|c|c|c|c|c|c|c|c|}
\hline \multicolumn{6}{|c|}{ Ratios } & \multicolumn{4}{|c|}{ Correlation matrix } \\
\hline Factors & $\begin{array}{r}\text { Aver- } \\
\text { age } \\
\end{array}$ & Median & $\begin{array}{l}\text { Std. } \\
\text { dev. }\end{array}$ & Min & Max & $\underline{\left[\mathrm{r}_{\mathrm{mt}}-\mathrm{r}_{\mathrm{ft}}\right]}$ & $\mathrm{SMB}_{\mathrm{t}}$ & $\mathrm{HML}_{\mathrm{t}}$ & $\mathrm{WML}_{\mathrm{t}}$ \\
\hline $\mathrm{r}_{\mathrm{ft}}$ & 0.30 & 0.11 & 0.99 & -0.49 & 4.83 & & & & \\
\hline $\mathrm{r}_{\mathrm{mt}}$ & 0.63 & 0.84 & 5.41 & -17.95 & 17.45 & & & & \\
\hline$\left[\mathrm{r}_{\mathrm{mt}}-\mathrm{r}_{\mathrm{ft}}\right]$ & 0.33 & 0.79 & 5.72 & -20.66 & 16.44 & 1.00 & 0.30 & -0.24 & 0.35 \\
\hline $\mathrm{SMB}_{\mathrm{t}}$ & 0.36 & 0.46 & 2.98 & -7.11 & 7.81 & -0.30 & 1.00 & 0.10 & 0.12 \\
\hline $\mathrm{HML}_{\mathrm{t}}$ & 0.17 & 0.15 & 1.77 & -5.60 & 5.29 & 0.24 & -0.10 & 1.00 & 0.34 \\
\hline $\mathrm{WML}_{\mathrm{t}}$ & 0.73 & 0.89 & 3.61 & -22.29 & 9.93 & -0.35 & -0.12 & -0.34 & 1.00 \\
\hline
\end{tabular}

Measures and correlation matrix of the independent variables $r_{f t}, r_{m t},\left[r_{m t}-r_{f t}\right], S M B_{t}, H M L_{t}$ and $W M L_{t}$ in the evaluation period between July $1^{\text {st }}, 2008$ and June $30^{\text {th }}, 2020$ ( $\mathrm{t}=1-144$ months).

Table 3 depicts the measures and correlation matrix. The table indicates that the correlation of the four risk factors, $\left[r_{m t}-r_{f t}\right], S M B_{t}, H M L_{t}$ and $W M L_{t}$, should not influence each other's results of the linear regression (multicollinearity). No constellation of the dependent variables reaches the critical value of $+/-0.50$. With $+/-0.35 \%$, the factors $\left[r_{m t}-r_{f t}\right]$ and $W M L_{t}$ show the highest correlation between two variables. The relation between $S M B_{t}$ and $H M L_{t}$ can be described as almost uncontrollable. 


\subsection{Test Portfolios}

Tables 4 and 5 summarize the descriptive statistic of one- and two-dimensionally assorted test portfolios. The results obtained from the panels which were constructed on the basis of the $\mathrm{BE} / \mathrm{ME}$ and WML criteria are of particular importance. By contrast, neither small nor big companies at the German stock market can present systematic excess returns.

Table 4: Monthly Excess Returns of One-dimensionally Assorted Portfolios

\begin{tabular}{|c|c|c|c|c|c|c|c|c|c|c|c|}
\hline & \multirow{3}{*}{ Decile } & \multicolumn{10}{|c|}{ Excess returns } \\
\hline & & 1 & 2 & 3 & 4 & 5 & 6 & 7 & 8 & 9 & 10 \\
\hline & & (low) & & & & & & & & & (high) \\
\hline \multirow{2}{*}{ Size } & Average & 0.33 & 0.41 & 0.24 & 0.72 & 0.64 & 0.63 & 0.44 & 0.57 & 0.42 & 0.21 \\
\hline & Std. Dev. & 5.36 & 5.23 & 5.30 & 5.45 & 6.23 & 5.76 & 6.06 & 5.78 & 5.90 & 5.69 \\
\hline \multirow{2}{*}{$\begin{array}{l}\mathrm{BE} \\
\mathrm{ME}\end{array}$} & Arith. Mittel & 0.37 & 0.51 & 0.35 & 0.56 & 0.24 & 0.10 & 0.48 & 0.70 & 0.62 & 0.93 \\
\hline & Std. Dev. & 5.52 & 5.43 & 5.38 & 5.60 & 5.73 & 5.59 & 5.09 & 5.53 & 5.69 & 6.14 \\
\hline \multirow{2}{*}{ WML } & Arith. Mittel & -0.01 & 0.20 & 0.16 & 0.31 & 0.44 & 0.46 & 0.46 & 0.68 & 0.96 & 1.05 \\
\hline & Std. Dev. & 8.10 & 6.26 & 5.99 & 5.37 & 5.49 & 4.86 & 4.87 & 4.79 & 5.06 & 5.84 \\
\hline
\end{tabular}

Monthly excess returns of one-dimensionally assorted portfolios in the evaluation period between July 1st, 2008 and June $30^{\text {th }}$, 2020, arranged according to the Size, BE/ME, and WML criteria $(\mathrm{t}=1-144$ months).

In the one-dimensionally assorted BE/ME panel, a steady growth of the returns in the test portfolios become apparent with an increasing book-market-ratio, which indicates the existence of a value effect in the evaluation period. While a monthly excess return of $0.37 \%$ is traceable in portfolio 1 , the values are increasing steadily until the highest return of $0.93 \%$ is reached in portfolio 10. Portfolios 5 and 6 form an exception. The two-dimensionally assorted portfolios confirm the results. The biggest differences between the first and the fourth quartile are apportioned to the BE/ME-WML panel. As such, the data on the BE/ME line up with the results of other studies on the German stock market (Ziegler et al. 2007, p. 371; Artmann et al. 2012, p. 29-30).

The same holds true for the outperformance of the winner stocks compared to the loser stocks, which indicates a momentum effect. In portfolio 1 , the average increase in value is still $-0.01 \%$, whereas a median capital growth of $1.05 \%$ is reached in portfolio 10. In two-dimensionally assorted portfolios, the winner stocks are also showing a clear outperformance compared to the loser stocks. The results are thus in line with the findings of (Carhart 1997, p. 64) and (Artmann et al. 2012, p. 30). 
Table 5: Monthly Excess Returns of Two-dimensionally Assorted Portfolios

\begin{tabular}{|c|c|c|c|c|c|}
\hline \multicolumn{6}{|c|}{ Excess Returns } \\
\hline & & \multicolumn{4}{|c|}{ Size } \\
\hline & & $\begin{array}{r}1 \\
\text { (low) }\end{array}$ & 2 & 3 & $\begin{array}{r}4 \\
\text { (high) }\end{array}$ \\
\hline \multirow{6}{*}{$\sum_{\substack{x=1 \\
\infty}}^{\infty}$} & 1 (low) & 0.07 & 0.41 & 0.67 & 0.41 \\
\hline & 2 & 0.10 & 0.62 & 0.66 & 0.20 \\
\hline & 3 & 0.40 & 0.41 & 0.24 & 0.49 \\
\hline & 4 (high) & 0.68 & 1.03 & 0.66 & 0.30 \\
\hline & & \multicolumn{4}{|c|}{ Size } \\
\hline & & $\begin{array}{r}1 \\
\text { (low) }\end{array}$ & 2 & 3 & $\begin{array}{r}4 \\
\text { (high) }\end{array}$ \\
\hline \multirow{6}{*}{$\sum_{i}^{B}$} & 1 (low) & -0.23 & -0.15 & 0.39 & 0.07 \\
\hline & 2 & 0.46 & 0.58 & 0.16 & 0.29 \\
\hline & 3 & 0.51 & 0.76 & 0.33 & 0.36 \\
\hline & 4 (high) & 1.05 & 1.12 & 1.20 & 0.47 \\
\hline & & \multicolumn{4}{|c|}{ BE/ME } \\
\hline & & $\begin{array}{r}1 \\
\text { (low) } \\
\end{array}$ & 2 & 3 & $\begin{array}{r}4 \\
\text { (high) }\end{array}$ \\
\hline \multirow{4}{*}{$\sum_{i}^{B}$} & 1 (low) & -0.56 & 0.01 & 0.21 & 0.45 \\
\hline & 2 & 0.21 & 0.21 & 0.42 & 0.60 \\
\hline & 3 & 0.51 & 0.45 & 0.48 & 0.46 \\
\hline & 4 (high) & 1.02 & 0.97 & 0.41 & 1.69 \\
\hline
\end{tabular}

Monthly excess returns of two-dimensionally assorted portfolios in the evaluation period between July $1^{\text {st }}, 2008$ and June $30^{\text {th }}, 2020$, arranged according to the Size, BE/ME, and WML criteria $(\mathrm{t}=1-144$ months).

The size effect is a different story, however. Small companies do not obtain a higher increase in value in the evaluation period than bigger companies. In the one-dimensional panel Size, the highest excess returns are concentrated in portfolios 4 to 6 . With $0.63 \%$ to $0.72 \%$, they are clearly above the rate of increase of the other portfolios. The smallest standard deviation was identified for portfolios 1 to 3 . The returns flatten toward decile 1 and 10. In the ME-BE/ME panel, the highest returns are to be found in quartiles 1 and 2. In the WML-BE/ME panel, an equal amount of returns is apportioned to quartiles 1 to 3 . Neither small nor big companies seem to have yielded excess returns in the evaluation period. Artmann et al. (2012) came to a similar conclusion. The average excess returns of the portfolios with a smaller market value obtain only 
insignificantly higher returns than those with the highest ME. Ziegler et. al. (2007), on the other hand, observe a clear trend in favor of smaller companies (Artmann et al. 2012, p. 30).

\section{Linear Time Series Regressions}

The following part of this work is divided into two sections. First, the influence of the risk factors on the excess returns of the one-dimensionally assorted panels is analyzed by means of the estimated regression coefficient and the corresponding t-values. The second section is dedicated to the analysis of the corrected $\mathrm{R}^{2}$ and the constant $\alpha_{i}$. These shall help reassess how well the regression model can represent the cross section of average German excess returns, whether one of the factor models does justice to the requirements of an equilibrium model and whether all relevant risks at the capital market are covered by it.

In order to validate the obtained results statistically, different statistical tests were initiated. All time series were tested for non-stationarity with the help of Augmented Dickey-Fuller Tests (Said und Dickey 1984, p. 599-607). In doing so, neither a random walk nor a random walk with a drift nor a deterministic trend could be detected in one of the time series, so that no pseudo regression can result here. The standard errors of the regression coefficient were estimated by using the correction method developed by Newey, Whitney and West (1987), as some regressions showed problems with auto correlation and, in particular, heteroscedasticity. Thanks to the correction method, the evidence of the statistical significance based on the $t$ - and p-value is reliably interpretable. With the financial crisis of 2008/2009, an exceptional event falls into the period of support (2008-2020), which is accompanied by strong swings in the data set (rogue results). For this reason, an additional estimation of the models ensued only from 2010 onward, serving as a robustness test. The results remained qualitative but unchanged. Hence, they will not be discussed in the following.

\subsection{Beta Factors and Corrected Coefficient of Determination}

In the following, it will examined how influential the independent variables $\left[r_{m t}-r_{f t}\right]$, $S M B_{t}, H M L_{t}$ and $W M L_{t}$ are on the excess returns of German stock returns. Tables 6 to 8 summarize the results of the three factor models for one-dimensionally assorted portfolios discussed here. In order to provide a better overview, the two-dimensionally assorted portfolios are not specifically designated. The estimated values resulting from the regressions of the three panels line up with the results of the one-dimensionally assorted portfolios and are available upon request. 


\subsubsection{One-factor model}

Table 6 summarizes the estimated regression coefficients of the one-dimensionally assorted panels Size, BE/ME, and WML for the one-factor model. An average risk premium of $0.33 \%$ developed from the descriptive statistics (cp. Table 3). In all evaluated portfolios, a significant influence of the variable on the excess returns of German securities can be seen. The estimated value of $\hat{\beta}_{i}$ ranges between 0.64 and 1.09. The comparison to Artmann et al. (2012) reveals clear parallels in the development of the estimated values. In the Size panel, a clear growth of the coefficient from 0.64 to 0.97 can be traced with increasing market value. A similar picture is emerging for the estimated values in the $\mathrm{BE} / \mathrm{ME}$ panel, although these show only moderate growth. The WML panel shows a decline of $\hat{\beta}_{i}$, with 1.09 in the first and up to 0.81 in the tenth decile and increasing performance of the securities (Artmann et al. 2012, p. 33-35).

\section{Table 6: Regression Coefficient of One-dimensionally Assorted Portfolios in the One-factor Model}

\begin{tabular}{|c|c|c|c|c|c|c|c|c|c|c|}
\hline \multicolumn{11}{|c|}{ CAPM } \\
\hline \multicolumn{11}{|c|}{$r_{i t}-r_{f t}=\alpha_{i}+\beta_{i}\left[r_{m t}-r_{f t}\right]+\varepsilon_{i t}$} \\
\hline \multirow[t]{2}{*}{ Decile } & $\begin{array}{l}1 \\
\text { (low) } \\
\end{array}$ & 2 & 3 & 4 & 5 & 6 & 7 & 8 & 9 & $\begin{array}{l}10 \\
\text { (high) } \\
\end{array}$ \\
\hline & \multicolumn{10}{|c|}{ Size } \\
\hline $\begin{array}{l}\widehat{\beta}_{i} \\
t \text {-Value }\end{array}$ & $\begin{array}{l}0.64 \text { *** } \\
11.25\end{array}$ & $\begin{array}{l}0.68 * * * \\
13.09\end{array}$ & $\begin{array}{l}0.71 * * * \\
14.20\end{array}$ & $\begin{array}{l}0.79 * * * \\
17.68\end{array}$ & $\begin{array}{l}0.95 * * * \\
21.08\end{array}$ & $\begin{array}{l}0.87^{* * *} \\
20.14\end{array}$ & $\begin{array}{l}0.92 * * * \\
21.22\end{array}$ & $\begin{array}{l}0.87^{* * * *} \\
20.54\end{array}$ & $\begin{array}{l}0.95 \text { *** } \\
27.36\end{array}$ & $\begin{array}{l}0.97^{* * *} \\
53.01\end{array}$ \\
\hline \multirow[t]{2}{*}{ Adj. $R^{2}$} & 0.47 & 0.54 & 0.58 & 0.69 & 0.76 & 0.74 & 0.76 & 0.75 & 0.84 & 0.95 \\
\hline & \multicolumn{10}{|c|}{ BE/ME } \\
\hline $\begin{array}{l}\widehat{\beta}_{i} \\
t \text {-Value }\end{array}$ & $\begin{array}{l}0.79 \text { *** } \\
17.01\end{array}$ & $\begin{array}{l}0.82 * * * \\
19.97\end{array}$ & $\begin{array}{l}0.83 \text { *** } \\
22.91\end{array}$ & $\begin{array}{l}0.86 \text { *** } \\
22.22\end{array}$ & $\begin{array}{l}0.86 * * * \\
19.88\end{array}$ & $\begin{array}{l}0.87^{* * *} \\
23.17^{*}\end{array}$ & $\begin{array}{l}0.77 * * * \\
20.34\end{array}$ & $\begin{array}{l}0.85 \text { *** } \\
22.10\end{array}$ & $\begin{array}{l}0.85 * * * \\
19.80\end{array}$ & $\begin{array}{l}0.86 * * * \\
15.79\end{array}$ \\
\hline \multirow[t]{2}{*}{ Adj. $R^{2}$} & 0.67 & 0.74 & 0.79 & 0.78 & 0.73 & 0.79 & 0.74 & 0.77 & 0.73 & 0.63 \\
\hline & \multicolumn{10}{|c|}{ WML } \\
\hline $\begin{array}{l}\widehat{\beta_{i}} \\
t \text {-Value }\end{array}$ & $\begin{array}{l}1.09^{\text {*** }} \\
14.33^{2}\end{array}$ & $\begin{array}{l}0.94 * * * \\
19.70\end{array}$ & $\begin{array}{l}0.911^{* * *} \\
20.99\end{array}$ & $\begin{array}{l}0.81 * * * \\
20.72\end{array}$ & $\begin{array}{l}0.84 \text { *** } \\
21.39\end{array}$ & $\begin{array}{l}0.74 \text { *** } \\
21.43\end{array}$ & $\begin{array}{l}0.76 \text { *** } \\
23.08\end{array}$ & $\begin{array}{l}0.72 * * * \\
20.23\end{array}$ & $\begin{array}{l}0.75^{\text {*** }} \\
19.10^{2}\end{array}$ & $\begin{array}{l}0.81^{* * *} \\
15.45^{*}\end{array}$ \\
\hline Adj. $R^{2}$ & 0.59 & 0.73 & 0.75 & 0.75 & 0.76 & 0.76 & 0.79 & 0.74 & 0.72 & 0.62 \\
\hline
\end{tabular}

$\mathrm{t}$-Value $\mid * * * \mathrm{P}-$ Value $<1 \%, * * \mathrm{P}$-Value $<3 \%, * \mathrm{P}-$ Value $<5 \%$

Estimated regression coefficient $\widehat{\beta}_{l}, \mathrm{t}$-value, and corrected $\mathrm{R}^{2}$ of the linear time series regression of one-dimensionally assorted portfolios on the basis of the Size, BE/ME, and WML criteria at the German stock market between July 2008 and June 2020 ( $\mathrm{t}=1-144$ months) for the one-factor model.

\subsubsection{Three-factor Model}

In Table 8 , the estimated coefficients for the three-factor model can be found. $\beta_{i 1}$ shows a similar behavior regarding the market risk premium $\left[r_{m t}-r_{f t}\right]$ as observed for the one-factor model. Once again, the variable has a significant influence on the excess returns of the securities 
in all panels. Compared to the one-factor model, the level of the coefficient increases to a range between 0.76 and 1.23, an effect which was seen already in earlier studies of the German stock market (Artmann et al. 2012, p. 33-35; Ziegler et al. 2007, p. 373).

While the descriptive statistic of the excess returns did not indicate a size-effect (cp. Table 4), the estimated regression coefficients of the risk factor $S M B_{t}$ paint a different picture. In all portfolios, the variable has a significant influence on the dependent variable. In the Size panel, $\hat{\beta}_{i 2}$ ranges between -0.10 and 0.91 . The highest coefficients are apportioned to deciles 1 to 5 . As of the sixth decile, the estimated values are declining successively until they reach the smallest coefficient in the decile with the highest market value, resulting, in combination with a risk premium of $0.36 \%$, in a higher rate of return for small companies. For bigger companies, however, a risk premium can be observed.

Previous works on the German stock market produced conflicting results. While the estimated values of the coefficient by Artmann et al. (2012) resemble the results presented here with regard to height and structure, a risk premium of $-0.18 \%$ was reported. According to them, higher returns were apportioned to companies with a high market value between 1962 and 2006. The data by Ziegler et al. (2007), however, paint a different picture, as they calculate a risk premium of 0.08 . With declining market value, an increase of $\hat{\beta}_{i 2}$ can be observed here as well. Due to the height of the risk premium, the influence of the variable is less important, though. The comparison to the American stock market shows that the second risk factor takes on a more central role on the US market (Artmann et al. 2012, p. 27, p. 33-35; Fama and French 1993, p. 24-25; Ziegler et al. 2007, p. 373).

On the other hand, the influence of the third risk factor turns out to be less strong, as previous studies on the three-factor model at the German stock market also showed. For the independent variable $H M L_{t}$ a risk premium of $0.17 \%$ was identified in the evaluation period (cp. Table 4). The excess returns generated a clear outperformance of companies with a high BE/ME (cp. Table 4). The estimated values for $\hat{\beta}_{i 3}$ should hence be sufficiently clear. This exception can be confirmed only partly, however. Companies with a high market value obtain a risk premium of -0.36 while a high substantial value of 0.50 goes along with it. On the one hand, the estimations in the one-dimensionally assorted BE/ME panel show a steady growth between the first and the tenth decile. On the other hand, the influence of the variable is less often significant. A similar, but less pronounced trend can be observed for the Size panel. Here, the estimated values increase slowly, from 0 in the first decile to 0.12 in the tenth decile. By contrast, $\hat{\beta}_{i 3}$ decreases in 
the WML panel with increasing performance of the stocks (Artmann et al. 2012, p. 27, p. 3335; Ziegler et al. 2007, p. 379).

Table 7: Regression Coefficient of One-dimensionally Assorted Portfolios in the Three-factor Model.

\begin{tabular}{|c|c|c|c|c|c|c|c|c|c|c|}
\hline \multicolumn{11}{|c|}{ Three-Factor Model } \\
\hline \multicolumn{11}{|c|}{$r_{i t}-r_{f t}=\alpha_{i}+\beta_{i 1}\left[r_{m t}-r_{f t}\right]+\beta_{i 2} S M B_{t}+\beta_{i 3} H M L_{t}+\varepsilon_{i t}$} \\
\hline \multirow[t]{2}{*}{$\begin{array}{c}\text { Decile- } \\
\text { Portfolios }\end{array}$} & (low) & 2 & 3 & 4 & 5 & 6 & 7 & 8 & 9 & $\begin{array}{l}10 \\
\text { (high) }\end{array}$ \\
\hline & \multicolumn{10}{|c|}{ Size } \\
\hline$\widehat{\beta_{i 1}}$ & $0.76 * * *$ & $0.80 * * *$ & $0.84 * * *$ & $0.92 * * *$ & $1.09 * * *$ & $0.94 * * *$ & $0.99 * * *$ & $0.95 * * *$ & $0.98 * * *$ & $0.95 * * *$ \\
\hline$t$-Value & 15.14 & 20.43 & 22.83 & 28.18 & 42.24 & 23.49 & 24.83 & 24.35 & 27.54 & 49.88 \\
\hline$\widehat{\beta_{i 2}}$ & $0.79 * * *$ & $0.88 * * *$ & $0.88 * * *$ & $0.79 * * *$ & $0.91 * * *$ & $0.52 * * *$ & $0.54 * * *$ & $0.54 * * *$ & $0.25 * * *$ & $-0.10 * * *$ \\
\hline t-Value & 8.36 & 11.93 & 12.72 & 12.91 & 18.97 & 6.96 & 7.28 & 7.34 & 3.77 & -2.93 \\
\hline$\widehat{\beta_{i 3}}$ & 0.00 & 0.11 & 0.05 & -0.10 & 0.01 & 0.06 & 0.23 & 0.05 & 0.03 & $0.12 *$ \\
\hline$t$-Value & 0.00 & 0.88 & 0.43 & -0.94 & 0.16 & 0.46 & 1.89 & 0.43 & 0.29 & 2.04 \\
\hline \multirow[t]{2}{*}{ Adj. $\mathrm{R}^{2}$} & 0.64 & 0.77 & 0.80 & 0.86 & 0.93 & 0.80 & 0.82 & 0.81 & 0.85 & 0.96 \\
\hline & \multicolumn{10}{|c|}{$\mathbf{B E} / \mathbf{M E}$} \\
\hline$\widehat{\beta_{i 1}}$ & $0.91 * * *$ & $0.93 * * *$ & $0.95 * * *$ & $0.96 * * *$ & $0.95 * * *$ & $0.93 * * *$ & $0.83 * * *$ & $0.90 * * *$ & $0.93 * * *$ & $0.95 * * *$ \\
\hline$t$-Value & 21.97 & 25.55 & 32.14 & 29.92 & 26.72 & 29.36 & 27.67 & 28.27 & 26.27 & 21.71 \\
\hline$\widehat{\beta_{i 2}}$ & $0.59 * * *$ & $0.46 * * *$ & $0.51 * * *$ & $0.60 * * *$ & $0.67 * * *$ & $0.54 * * *$ & $0.58 * * *$ & $0.54 * * *$ & $0.65 * * *$ & $0.82 * * *$ \\
\hline$t$-Value & 7.62 & 6.81 & 9.27 & 10.09 & 10.00 & 9.11 & 10.35 & 9.10 & 9.83 & 10.12 \\
\hline$\widehat{\beta_{i 3}}$ & $-0.36 * * *$ & $-0.51 * * *$ & $-0.43 * * *$ & -0.01 & 0.11 & $0.26 * * *$ & $0.36 * * *$ & $0.41 * * *$ & $0.31 * * *$ & $0.50 * * *$ \\
\hline$t$-Value & -2.79 & -4.52 & -4.74 & -0.08 & 1.00 & 2.61 & 3.87 & 4.17 & 2.85 & 3.71 \\
\hline \multirow[t]{2}{*}{ Adj. $\mathrm{R}^{2}$} & 0.77 & 0.82 & 0.88 & 0.87 & 0.84 & 0.87 & 0.86 & 0.86 & 0.84 & 0.80 \\
\hline & \multicolumn{10}{|c|}{ WML } \\
\hline$\widehat{\beta_{i 1}}$ & $1.23 * * *$ & $1.02 * * *$ & $0.98 * * *$ & $0.91 * * *$ & $0.91 * * *$ & $0.81 * * *$ & $0.83 * * *$ & $0.78 * * *$ & $0.84 * * *$ & $0.95 * * *$ \\
\hline$t$-Value & 19.11 & 25.18 & 27.00 & 26.93 & 28.81 & 26.68 & 28.47 & 22.65 & 23.36 & 20.32 \\
\hline$\widehat{\beta_{i 2}}$ & $1.11 * * *$ & $0.68 * * *$ & $0.63 * * *$ & $0.57 * * *$ & $0.61 * * *$ & $0.48 * * *$ & $0.44 * * *$ & $0.38 * * *$ & $0.49 * * *$ & $0.64 * * *$ \\
\hline$t$-Value & 9.27 & 9.03 & 9.26 & 9.15 & 10.28 & 8.44 & 8.03 & 5.87 & 7.32 & 7.37 \\
\hline$\widehat{\beta_{i 3}}$ & $0.43 *$ & $0.27 *$ & $0.35 * * *$ & -0.04 & $0.24 * *$ & 0.03 & -0.10 & -0.04 & -0.16 & $-0.50 * * *$ \\
\hline t-Value & 2.17 & 2.17 & 3.14 & -0.34 & 2.41 & 0.31 & -1.14 & -0.33 & -1.46 & -3.45 \\
\hline Adj. $\mathrm{R}^{2}$ & 0.75 & 0.83 & 0.85 & 0.84 & 0.86 & 0.84 & 0.85 & 0.79 & 0.80 & 0.74 \\
\hline
\end{tabular}

$\mathrm{t}-$ Value $\mid * * * \mathrm{P}-$ Value $<1 \%, * * \mathrm{P}$-Value $<3 \%, * \mathrm{P}$-Value $<5 \%$

Estimated regression coefficients $\beta_{1-3}$, t-values, and corrected $\mathrm{R}^{2}$ of the linear time series regression of one-dimensionally assorted portfolios on the basis of the Size, BE/ME, and WML criteria at the German stock market between July 2008 and June 2020 ( $\mathrm{t}=1-144$ months) for the three-factor model.

\subsubsection{Four-factor Model}

The results of the linear time series regressions for the four-factor model are summarized in Table 9. As was observable for the results of the three-factor model, the risk factors $\left[r_{m t}-r_{f t}\right]$ and $S M B_{t}$ have a significant influence on the dependent variables of the one-dimensionally assorted portfolios. By contrast, $H M L_{t}$ takes on a less important role for the explanation of German security returns in the evaluation period. Compared to the regression coefficients of 
the three-factor model summarized in Table 8, the standard of the estimated values is sinking across all portfolios.

The results for the fourth risk factor, for whom the highest risk premium of $0.73 \%$ was calculated in the context of descriptive statistics (cp. Table 3), are remarkable. The outperformance of the winner stocks within the test portfolios also indicate a "momentum-effect" in the evaluation period (cp. Table 4 and 5). The previously collected results are supported by the estimated values resulting from the regressions of the four-factor model, which tend to be bigger with increasing share of the winner stocks. While $\hat{\beta}_{i 4}$ amounts to -0.94 in the first decile of the WML panel, the maximum value of 0.47 is reached in the tenth decile. Securities with a bad return performance will hence be punished with a return discount while the winner stocks receive a risk premium. Moreover, the fourth risk factor has a significant influence on the dependent variable in almost all deciles. On the whole, the depicted results support the work by Artmann et al. (2012), whose estimations range from -0.89 in the first decile to 0.40 in the tenth decile, hence resembling the estimated values discussed here. Carhart (1997) observes the same effect at the American stock market between 1963 and 1993. However, the coefficients are a lot smaller here (Carhart 1997, p. 64; Artmann et al. 2012, p. 33-35).

In the Size panel, six of the ten analyzed portfolios have high t-values. Nine out of ten coefficients show an estimated value of less than 0 , with upward tendency. This tendency was also observed at the German stock market between 1962 and 2006, and it fits to the results of the descriptive statistic in which a negative correlation between the risk factors $S M B_{t}$ and $W M L_{t}$ was identified (cp. Table 3). Contrary to the work by Artmann et al. (2012), however, a decreasing estimated value becomes apparent with increasing substantial value for the BE/ME panel. Only three portfolios have a significant influence on the dependent variable (Artmann et al. 2012, p. 33-35).

The analysis of the regression coefficient revealed that the risk factor $\left[r_{m t}-r_{f t}\right]$ takes on a dominant role for all models. Moreover, the data shows that the company size, depicted as $S M B_{t}$, forms an important contribution to the explanation of excess returns at the German stock market. Between 2008 and 2020, securities with a low market value received a risk premium at the German stock market. In the past, similar studies produced contradictory results.

Compared internationally, e.g. to the United States, the risk factor $H M L_{t}$ has a less significant role. While the structure of the regression coefficient and the outperformance of the respective test portfolios show that companies with a high $\mathrm{BE} / \mathrm{ME}$ generate higher returns, compared to 
other risk factors, their estimated coefficients tend to be smaller and they less often have a significant influence on the excess returns of German stocks. By contrast, the fourth risk factor $W M L_{t}$ shows a stronger influence. This influence shows in a distinctive structure of the estimated coefficients in favor of the winner stocks as well as high t-factors, which show the according influence of the variable.

Table 8: Regression Coefficient of One-dimensionally Assorted Portfolios in the Four-factor model

\begin{tabular}{|c|c|c|c|c|c|c|c|c|c|c|}
\hline \multicolumn{11}{|c|}{ Four-Factor Model } \\
\hline \multicolumn{11}{|c|}{$r_{i t}-r_{f t}=\alpha_{i}+\beta_{i 1}\left[r_{m t}-r_{f t}\right]+\beta_{i 2} S M B_{t}+\beta_{i 3} H M L_{t}+\beta_{i 4} W M L_{t}+\varepsilon_{i t}$} \\
\hline \multirow[t]{2}{*}{$\begin{array}{c}\text { Decile- } \\
\text { Portfolios }\end{array}$} & $\begin{array}{l}1 \\
\text { (low) }\end{array}$ & 2 & 3 & 4 & 5 & 6 & 7 & 8 & 9 & $\begin{array}{l}10 \\
\text { (high) }\end{array}$ \\
\hline & \multicolumn{10}{|c|}{ Size } \\
\hline $\begin{array}{l}\widehat{\beta_{i 1}} \\
t \text {-Value }\end{array}$ & $\begin{array}{l}0.72 \text { *** } \\
13.55\end{array}$ & $\begin{array}{l}0.80 \text { *** } \\
18.94\end{array}$ & $\begin{array}{l}0.83 \text { *** } \\
20.99\end{array}$ & $\begin{array}{l}0.93^{* * *} \\
26.85\end{array}$ & $\begin{array}{l}1.06 * * * \\
39.42\end{array}$ & $\begin{array}{l}0.93 \text { *** } \\
21.61\end{array}$ & $\begin{array}{l}0.95 * * * \\
22.75\end{array}$ & $\begin{array}{l}0.92 * * * \\
22.29\end{array}$ & $\begin{array}{l}0.95 * * * \\
25.31\end{array}$ & $\begin{array}{l}0.93 \text { *** } \\
46.45\end{array}$ \\
\hline $\begin{array}{l}\widehat{\beta_{i 2}} \\
t \text {-Value }\end{array}$ & $\begin{array}{l}0.73 * * * \\
7.55\end{array}$ & $\begin{array}{l}0.87^{\text {*** }} \\
11.38\end{array}$ & $\begin{array}{l}0.86 \text { *** } \\
11.98\end{array}$ & $\begin{array}{l}0.81 \text { *** } \\
12.80\end{array}$ & $\begin{array}{l}0.88 * * * \\
17.94\end{array}$ & $\begin{array}{l}0.50 \text { *** } \\
6.44\end{array}$ & $\begin{array}{l}0.49^{* * *} \\
6.48\end{array}$ & $\begin{array}{l}0.49 * * * \\
6.65\end{array}$ & $\begin{array}{l}0.21^{* * *} \\
3.11\end{array}$ & $\begin{array}{l}-0.12 \text { **** } \\
-3.44\end{array}$ \\
\hline$\widehat{\beta_{i 3}}$ & -0.11 & 0.10 & 0.15 & -0.06 & -0.05 & 0.03 & 0.15 & -0.04 & -0.04 & 0.08 \\
\hline$t$-Value & -0.68 & 0.76 & 0.13 & -0.53 & -0.65 & 0.17 & 1.14 & -0.29 & -0.33 & 1.35 \\
\hline $\begin{array}{l}\widehat{\beta_{i 4}} \\
t \text {-Value }\end{array}$ & $\begin{array}{l}-0.20 * * \\
-2.31\end{array}$ & $\begin{array}{l}-0.02 \\
-0.26\end{array}$ & $\begin{array}{l}-0.06 \\
-0.97\end{array}$ & $\begin{array}{l}0.07 \\
1.27\end{array}$ & $\begin{array}{l}-0.12 * * * \\
-2.77\end{array}$ & $\begin{array}{l}-0.06 \\
-0.95\end{array}$ & $\begin{array}{l}-0.16 * * \\
-2.38\end{array}$ & $\begin{array}{l}-0.16 * * \\
-2.39\end{array}$ & $\begin{array}{l}-0.12 * \\
-2.08\end{array}$ & $\begin{array}{l}-0.07 * \\
-2.13\end{array}$ \\
\hline \multirow[t]{2}{*}{ Adj. $R^{2}$} & 0.65 & 0.77 & 0.80 & 0.86 & 0.93 & 0.80 & 0.83 & 0.82 & 0.86 & 0.96 \\
\hline & \multicolumn{10}{|c|}{ BE/ME } \\
\hline $\begin{array}{l}\widehat{\beta_{i 1}} \\
t \text {-Value }\end{array}$ & $\begin{array}{l}0.90 * * * \\
20.27\end{array}$ & $\begin{array}{l}0.91 \text { **** } \\
23.52\end{array}$ & $\begin{array}{l}0.93 * * * \\
29.67\end{array}$ & $\begin{array}{l}0.94 * * * \\
27.59\end{array}$ & $\begin{array}{l}0.96 * * * \\
25.15\end{array}$ & $\begin{array}{l}0.93 * * * \\
27.26\end{array}$ & $\begin{array}{l}0.81 * * * \\
25.43\end{array}$ & $\begin{array}{l}0.87 \text { *** } \\
26.06\end{array}$ & $\begin{array}{l}0.89 * * * \\
24.15\end{array}$ & $\begin{array}{l}0.89 \text { *** } \\
19.88\end{array}$ \\
\hline $\begin{array}{l}\widehat{\beta_{i 2}} \\
t \text {-Value }\end{array}$ & $\begin{array}{l}0.58 * * * \\
7.16\end{array}$ & $\begin{array}{l}0.44 * * * \\
6.27\end{array}$ & $\begin{array}{l}0.49^{* * * *} \\
8.64\end{array}$ & $\begin{array}{l}0.58 * * * \\
9.42\end{array}$ & $\begin{array}{l}0.68 * * * \\
9.78\end{array}$ & $\begin{array}{l}0.54 \text { *** } \\
8.68\end{array}$ & $\begin{array}{l}0.55^{* * *} \\
9.58\end{array}$ & $\begin{array}{l}0.50 * * * \\
8.22\end{array}$ & $\begin{array}{l}0.60 * * * \\
8.93\end{array}$ & $\begin{array}{l}0.74^{\text {*** }} \\
9.18\end{array}$ \\
\hline $\begin{array}{l}\widehat{\beta_{i 3}} \\
t \text {-Value }\end{array}$ & $\begin{array}{l}-0.38 * * * \\
-2.83\end{array}$ & $\begin{array}{l}-0.55 \text { **** } \\
-4.63\end{array}$ & $\begin{array}{l}-0.46^{* * *} \\
-4.85\end{array}$ & $\begin{array}{l}-0.04 \\
-0.40\end{array}$ & $\begin{array}{l}0.13 \\
1.15\end{array}$ & $\begin{array}{l}0.25 \text { ** } \\
2.42\end{array}$ & $\begin{array}{l}0.31^{* * *} \\
3.24\end{array}$ & $\begin{array}{l}0.33 * \\
3.28\end{array}$ & $\begin{array}{l}0.22 \\
1.97\end{array}$ & $\begin{array}{l}0.35^{* * *} \\
2.61\end{array}$ \\
\hline$\widehat{\beta_{i 4}}$ & -0.04 & -0.07 & -0.05 & -0.06 & 0.04 & -0.01 & -0.08 & $-0.15 * * *$ & $-0.16 * * *$ & $-0.26 * * *$ \\
\hline$t$-Value & -0.59 & -1.07 & -1.08 & -1.13 & 0.65 & -0.24 & -1.63 & -2.75 & -2.79 & -3.73 \\
\hline \multirow[t]{2}{*}{ Adj. $\mathrm{R}^{2}$} & 0.77 & 0.82 & 0.88 & 0.87 & 0.84 & 0.87 & 0.86 & 0.87 & 0.85 & 0.81 \\
\hline & \multicolumn{10}{|c|}{ WML } \\
\hline $\begin{array}{l}\widehat{\beta_{i 1}} \\
t \text {-Value }\end{array}$ & $\begin{array}{l}1.02 * * * \\
21.44\end{array}$ & $\begin{array}{l}0.91 * * * \\
26.57\end{array}$ & $\begin{array}{l}0.88 * * * \\
28.79\end{array}$ & $\begin{array}{l}0.87 * * * \\
24.82\end{array}$ & $\begin{array}{l}0.88 * * * \\
26.62\end{array}$ & $\begin{array}{l}0.82 * * * \\
25.06\end{array}$ & $\begin{array}{l}0.87^{* * *} \\
28.47\end{array}$ & $\begin{array}{l}0.86 \text { *** } \\
26.09\end{array}$ & $\begin{array}{l}0.92 * * * \\
28.29\end{array}$ & $\begin{array}{l}1.05 \text { *** } \\
24.38\end{array}$ \\
\hline $\begin{array}{l}\widehat{\beta_{i 2}} \\
t \text {-Value }\end{array}$ & $\begin{array}{l}0.82 * * * \\
9.56\end{array}$ & $\begin{array}{l}0.53 \text { *** } \\
8.52\end{array}$ & $\begin{array}{l}0.49^{* * *} \\
8.81\end{array}$ & $\begin{array}{l}0.52 \text { *** } \\
8.24\end{array}$ & $\begin{array}{l}0.56 * * * \\
9.36\end{array}$ & $\begin{array}{l}0.49^{* * * *} \\
8.25\end{array}$ & $\begin{array}{l}0.48 * * * \\
8.78\end{array}$ & $\begin{array}{l}0.48 * * * \\
8.06\end{array}$ & $\begin{array}{l}0.61 * * * \\
10.29\end{array}$ & $\begin{array}{l}0.79 \text { *** } \\
10.05\end{array}$ \\
\hline$\widehat{\beta_{i 3}}$ & -0.09 & -0.01 & 0.10 & -0.13 & 0.15 & 0.04 & -0.02 & 0.15 & 0.05 & -0.23 \\
\hline$t$-Value & -0.64 & -0.10 & 1.07 & -1.22 & 1.49 & 0.45 & -0.23 & 1.48 & 0.53 & -1.78 \\
\hline $\begin{array}{l}\widehat{\beta_{i 4}} \\
\text { t-Value }\end{array}$ & $\begin{array}{l}-0.94 * * * \\
-12.42\end{array}$ & $\begin{array}{l}-0.51 * * * \\
-9.32\end{array}$ & $\begin{array}{l}-0.45 * * * \\
-9.37\end{array}$ & $\begin{array}{l}-0.17 * * * \\
-3.01\end{array}$ & $\begin{array}{l}-0.16 * * * \\
-3.01\end{array}$ & $\begin{array}{l}0.03 \\
0.53\end{array}$ & $\begin{array}{l}0.15^{* * *} \\
3.05^{2}\end{array}$ & $\begin{array}{l}0.33^{* * * *} \\
6.24^{2}\end{array}$ & $\begin{array}{l}0.38 * * * \\
7.39\end{array}$ & $\begin{array}{l}0.47 \text { **** } \\
6.90\end{array}$ \\
\hline Adj. $R^{2}$ & 0.88 & 0.89 & 0.91 & 0.85 & 0.87 & 0.84 & 0.86 & 0.83 & 0.85 & 0.81 \\
\hline
\end{tabular}

$\mathrm{t}$-Value $\mid * * *$ P-Value $<1 \%$, ** P-Value $<3 \%, *$ P-Value $<5 \%$ 
Estimated regression coefficients $\beta_{1-4}$, t-values and corrected $\mathrm{R}^{2}$ of the linear time series regressions of onedimensionally assorted portfolios on the basis of the Size, BE/ME, and WML at the German stock market in the evaluation period between July 2008 and June 2020 ( $\mathrm{t}=1-144$ months) for the four-factor model.

\subsection{Analysis of the Alpha Constant}

The second part of this study is dedicated to the analysis of the estimated constant $\hat{\alpha}_{i}$ und the corrected $\mathrm{R}^{2}$. Fama and French (1993) claim that an $\hat{\alpha}_{i}$ of zero indicates that a factor model represents all relevant risk factors at the capital market. Here, the authors draw on the GRS statistic developed by Gibbons et al. (1989). With the help of the f-tests, the null hypothesis is reassessed, examining whether the estimated constants of a panel's regressions deviate significantly from zero. If the hypothesis is discarded, it can be assumed that the model cannot represent all relevant risk factors at the capital market. The corrected $\mathrm{R}^{2}$, on the other hand, is of empirical relevance as it indicates how well a regression model can represent the cross section of observations (Fama and French 1993, p. 39).

Table 12 and 13 summarize the relevant data for the one-dimensionally as well as two-dimensionally assorted panels in the evaluation period between July 2008 and June 2020 for the one-, two-, three-, and four-factor model at the German stock market. Looking at the one-dimensionally assorted portfolios, one can see that with every added risk factor, the level of the estimated values decreases. It is particularly noteworthy that $\hat{\alpha}_{i}$ is at its highest where the sorting criterion of a panel is not represented by the factor model. For example, the evaluations of the one- and three-factor model in the WML panel are the highest while the constant in the fourfactor model approaches zero.

The GRS statistic shows that the three-factor model meets the requirements of an equilibrium model best and that it does not reject the underlying null hypothesis in a one-dimensionally assorted panel. The one- and four-factor models withstand a respective revision only in one, respectively two panels. While the three-factor model produced the best results of the GRS statistic for one-dimensionally assorted portfolios, the model developed by Carhart (1997) does so for the two-dimensionally assorted portfolios. The four-factor model does not discard the respective null hypothesis in either of the analyzed portfolios. By contrast, the one- and threefactor models do not withstand a revision through the GRS statistic in two out of three panels. 
Table 9: Constant $\alpha_{i}$ of One-dimensionally Assorted Portfolios

\begin{tabular}{|c|c|c|c|c|c|c|c|c|c|c|c|c|}
\hline & & & \multicolumn{10}{|c|}{ Decile } \\
\hline & & & $\begin{array}{r}1 \\
\text { (low) } \\
\end{array}$ & 2 & 3 & 4 & 5 & 6 & 7 & 8 & 9 & $\begin{array}{r}10 \\
\text { (high) }\end{array}$ \\
\hline \multirow{9}{*}{$\sum_{j}$} & \multirow{3}{*}{ Size } & & \multicolumn{10}{|c|}{$\mathrm{FGRS}=0,82 \mathrm{pGRS}=0,61$} \\
\hline & & Alpha & 0.12 & 0.18 & 0.01 & 0.45 & 0.33 & 0.35 & 0.14 & 0.28 & 0.11 & -0.11 \\
\hline & & t-Value & 0.36 & 0.62 & 0.02 & 1.78 & 1.27 & 1.41 & 0.55 & 1.16 & 0.55 & -1.02 \\
\hline & \multirow{3}{*}{$\begin{array}{l}\mathrm{BE} \\
\mathrm{ME}\end{array}$} & & \multicolumn{10}{|c|}{$\mathrm{FGRS}=2,00 \mathrm{pGRS}=0,04$} \\
\hline & & Alpha & 0.10 & 0.24 & 0.07 & 0.28 & -0.05 & -0.19 & 0.22 & 0.42 & 0.34 & $0.64 *$ \\
\hline & & t-Value & 0.39 & 1.02 & 0.36 & 1.26 & -0.19 & -0.87 & 1.04 & 1.91 & 1.38 & 2.08 \\
\hline & \multirow{3}{*}{ WML } & & \multicolumn{10}{|c|}{$\mathrm{FGRS}=1,59 \mathrm{pGRS}=0,12$} \\
\hline & & Alpha & -0.37 & -0.11 & -0.14 & 0.04 & 0.17 & 0.22 & 0.21 & $0.44 *$ & $0.71 * * *$ & $0.78 * *$ \\
\hline & & t-Value & -0.86 & -0.40 & -0.58 & 0.19 & 0.74 & 1.10 & 1.12 & 2.17 & 3.18 & 2.61 \\
\hline \multirow{9}{*}{ 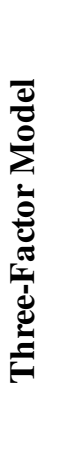 } & \multirow{3}{*}{ Size } & & \multicolumn{10}{|c|}{$\mathrm{FGRS}=0,68 \mathrm{pGRS}=0,74$} \\
\hline & & Alpha & -0.21 & -0.20 & -0.37 & 0.14 & -0.05 & 0.12 & -0.12 & 0.05 & 0.00 & -0.08 \\
\hline & & $t$-Value & -0.78 & -0.93 & -1.84 & 0.80 & -0.39 & 0.56 & -0.57 & 0.25 & 0.00 & -0.79 \\
\hline & \multirow{3}{*}{$\begin{array}{l}\mathrm{BE} \\
\mathrm{ME}\end{array}$} & & \multicolumn{10}{|c|}{$\mathrm{FGRS}=1,85 \mathrm{pGRS}=0,06$} \\
\hline & & Alpha & -0.09 & 0.12 & -0.08 & 0.03 & -0.34 & $-0.45 * *$ & -0.07 & 0.13 & 0.03 & 0.23 \\
\hline & & t-Value & -0.40 & 0.61 & -0.48 & 0.17 & -1.77 & -2.62 & -0.42 & 0.78 & 0.13 & 0.98 \\
\hline & \multirow{3}{*}{ WML } & & \multicolumn{10}{|c|}{$\mathrm{FGRS}=1,62 \mathrm{pGRS}=0,11$} \\
\hline & & Alpha & $-0.90 * *$ & -0.43 & $-0.45 * *$ & -0.19 & -0.12 & 0.01 & 0.04 & 0.29 & $0.53 * * *$ & $0.59 * *$ \\
\hline & & t-Value & -2.59 & -1.97 & -2.32 & -1.05 & -0.70 & 0.09 & 0.27 & 1.56 & 2.75 & 2.34 \\
\hline \multirow{9}{*}{ 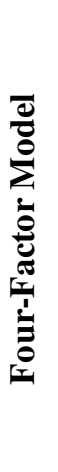 } & \multirow{3}{*}{ Size } & & \multicolumn{10}{|c|}{$\mathrm{FGRS}=0,57 \mathrm{pGRS}=0,84$} \\
\hline & & Alpha & -0.01 & -0.18 & -0.30 & 0.07 & 0.07 & 0.19 & 0.04 & 0.21 & 0.13 & -0.01 \\
\hline & & $t$-Value & -0.05 & -0.80 & -1.46 & 0.38 & 0.46 & 0.82 & 0.18 & 0.97 & 0.63 & -0.12 \\
\hline & \multirow{3}{*}{$\begin{array}{l}\mathrm{BE} \\
\mathrm{ME}\end{array}$} & & \multicolumn{10}{|c|}{$\mathrm{FGRS}=2,97 \mathrm{pGRS}=0,00$} \\
\hline & & Alpha & -0.05 & 0.19 & -0.02 & 0.09 & -0.38 & $-0.44 * *$ & 0.02 & 0.28 & 0.19 & $0.50 *$ \\
\hline & & $t$-Value & -0.21 & 0.91 & -0.13 & 0.50 & -1.88 & -2.41 & 0.09 & 1.60 & 0.98 & 2.11 \\
\hline & \multirow{3}{*}{ WML } & & \multicolumn{10}{|c|}{$\mathrm{FGRS}=0,27 \mathrm{pGRS}=0,99$} \\
\hline & & Alpha & 0.05 & 0.08 & 0.01 & -0.02 & 0.04 & -0.01 & -0.11 & -0.04 & 0.14 & 0.11 \\
\hline & & t-Value & 0.20 & 0.45 & 0.03 & -0.11 & 0.22 & -0.08 & -0.66 & -0.22 & 0.83 & 0.47 \\
\hline
\end{tabular}

t-Value $\mid * * *$ P-Value $<1 \%, * *$ P-Value $<3 \%$, $*$ P-Value $<5 \%$

FGRS H0: Every $\alpha=0$

Estimated constant $\alpha_{i}$, t-values, and GRS-statistic of the linear time series regressions of one-dimensionally assorted portfolios on the basis of the Size, BE/ME, and WML criteria at the German stock market in the evaluation period between July 2008 and June 2020 ( $\mathrm{t}=1-144$ months).

The WML panel examined by Carhart (1997) shows a similar behavior of constant $\hat{\alpha}_{i}$ for the one- and four-factor models at the American stock market. Fama and French (1993) identify an $\hat{\alpha}_{i}$ between -0.34 and 0.21 for their model. However, the three-factor model does not withstand a revision through the GRS statistic. Previous studies on the German stock market produced contradictory results here. Hence, Ziegler et al. (2007) were not able to discard the null hypotehsis of the GRS statistic for the three-factor model in either of the 16 portfolios. While Artmann et al. (2012) come up with a different result as their panel rejects the respective null 
hypothesis for the three-factor model, the overall structure of the estimated values of their work resembles the results discussed here. Overall, however, the coefficients tend to be higher, which is mirrored in a proportionally higher rejection rate of the GRS statistic (Carhart 1997; Fama und French 1993, p. 36-37; p. 41; Ziegler et al. 2007, p. 384; Artmann et al. 2012, p. 3739).

Out of all the models analyzed here, the four-factor model marks the highest explanatory contribution for the cross section of average German stock returns during and after the financial crisis. While only minimal growth can be observed in the one-dimensionally assorted Size and $\mathrm{BE} / \mathrm{ME}$ panels, the corrected $\mathrm{R}^{2}$ in the WML panel is growing most significantly. As shown in the analysis of the three-factor model by Fama and French (1993), however, Carhart's model (1997) has a significantly higher explanatory power at the American stock market. Compared to the one- and three-factor model, Artmann et al. (2012) also attest the four-factor model higher explanatory power for the cross section of average German stock returns. The average corrected $\mathrm{R}^{2}$ tends to be slightly lower, ranging between 0.66 and 0.72 (Carhart 1997, p. 64; Artmann et al. 2012, p. 37-39). 
Table 13: $\alpha_{i}$ on double sorted portfolios

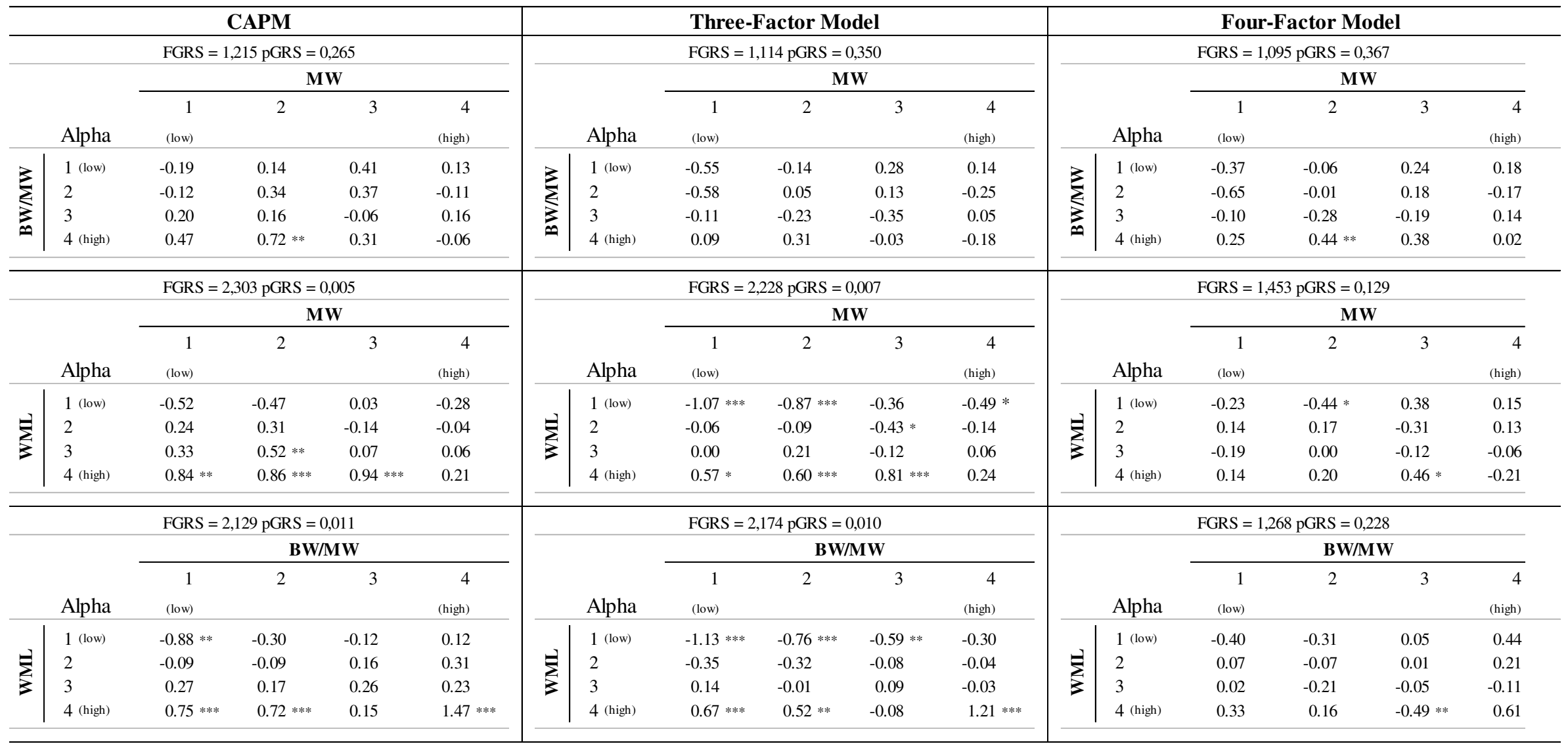

t-Value $\mid * * *$ P-Value $<1 \%, * *$ P-Value $<3 \%$, P-Value $<5 \%$

FGRS H0: Alle $\alpha=0$

Estimated ai, t-Valuee and GRS-Statistic as result of time series regressions on double sorted portfolios, based on ME, BM/ME and WML on the German stock market between July 2008 and June 2020 ( $t=1-144$ Months) 
In summary, it can be noted that the four-factor model depicts the cross section of German stock returns between 2008 and 2020 best. However, the additional explanatory contribution of the variable $W M L_{t}$ is minor compared to the three-factor model and is, for the most part, limited to portfolios which are constructed on the basis of the WML criterion. From an empirical point of view, an expansion of the CAPM seems definitely recommendable, though.

The analysis of the constant $\hat{\alpha}_{i}$ on the German stock market has shown that, out of all portfolios, the four-factor model is suited best for depicting the systematic risks. The threefactor model withstands a respective revision less often. Here, weaknesses are recognizable especially in the two-dimensionally assorted portfolios. However, even though the model by Fama and French does not represent all risk factors of the capital market, it depicts the cross section of average returns almost as well as the four-factor model by Carhart. Regarding the CAPM-compatible one-factor model, it can be noted that it does not withstand the requirements of an equilibrium model. An expansion of the model is hence recommendable both from a theoretical as well as from an empirical point of view.

\section{Summary and Prospect}

This study focuses on the analysis of multi-factor models in the time after the financial crisis at the German stock market. The models analyzed here include the CAPM-compatible onefactor model, the three-factor model by Fama and French (1993) as well as the four-factor model by Carhart (1997). The key questions are: which of the three models depicts the cross section of average German stock market returns best and in how far is an expansion of the CAPM feasible.

The regression results show that the four-factor model explains the cross section of average German stock returns between 2008 and 2020 best. However, the three-factor model also has a significant explanatory power, which corresponds with the results of other studies on the German stock market. Regarding the estimated constant $\hat{\alpha}_{i}$, the four-factor model also shows the best results. For 5 out of 6 panels, the GRS statistic indicates that the model developed by Carhart depicts all relevant risk factors of the capital market. Previous studies produced conflicting results here.

The analysis of the estimated regression coefficients showed that the risk factor $\left[r_{m t}-r_{f t}\right]$ continues to have a dominant role for all analyzed factor models. Particularly the results for the 
risk factor $S M B_{t}$, which was constructed on the basis of the market capitalization, are remarkable. While the Size portfolios did not indicate a conclusive tendency regarding the increase in value of smaller or bigger companies, the risk factor of both the three- and four-factor model formed a significant contribution to the explanation of German excess returns. The structure of the estimated coefficient suggests that small companies received a respective risk premium in the evaluation period. The risk factors $H M L_{t}$ and $W M L_{t}$ are less influential, however. Both regression coefficients are less often significant and tend to come up where BE/ME and WML serve as construction characteristics of the portfolios. It is interesting to note that both for companies with a higher book-market-ratio as well as for winner stocks from the descriptive statistic, a clear outperformance over their respective equivalent could be observed.

The results of this paper and the comparison to previous studies on the German stock market show that the valuation of the risk premiums has changed over the years. Future studies could therefore explore the causes of this development. Moreover, the data generated in this study could be combined with that of previous studies in order to strengthen the empirical explanatory power.

\section{References}

Artmann, Sabine; Finter, Philipp; Kempf, Alexander; Koch, Stefan; Theissen, Erik (2012): The Cross-Section of German Stock Returns: New Data and New Evidence. In: Schmalenbach Business Review (64), p. 20-43.

Black, Fischer; Jensen, Michael C.; Scholes, Myron (1972): The Capital Asset Pricing Model: Some Empirical Tests. In: Studies in the Theory of Capital Markets, p. 79-121.

Banz, Rolf W. (1981): The Relationship Between Return and Market Value of Common Stocks. In: Journal of Financial Economics (9), p. 3-18.

Breeden, Douglas T.; Gibbons, Michael R.; Litzenberger, Robert H. (1989): Empirical Test of the Consumption-Oriented CAPM. In: The Journal of Finance (44), p. 231-262.

Carhart, Mark M. (1997): On Persistence in Mutual Fund Performance. In: The Journal of Finance (52), p. 57-82.

Fama, Eugene F.; French, Kenneth R. (1992): The Cross-Section of Expected Stock Returns. In: The Journal of Finance (47), p. 427-465.

Fama, Eugene F.; French, Kenneth R. (1993): Common risk factors in the returns on stocks and bonds. In: Journal of Financial Economics (33), p. 3-56.

Fama, Eugene F.; French, Kenneth R. (1995): Size and Book-to-Market Factors in Earnings and Returns. In: The Journal of Finance (50), p. 131-155.

Fama, Eugene F.; French, Kenneth R. (2004): The Capital Asset Pricing Model: Theory and Evidence. In: Journal of Economic Perspectives (18), p. 25-46. 
Gibbons, Michael R.; Ross, Stephen A.; Shanken, Jay (1989): A test of the efficiency of a given portfolio. In: Econometrica (57), p. 1121-1152.

Jegadeesh, Narasimhan; Titman, Sheridan (1993): Returns to Buying Winners and Selling Losers: Implications for Stock Market Efficiency. In: The Journal of Finance (48), p. 65-91.

Kent, Daniel; Sheridan, Titman; Wei, K. JohnC. (2001): Explaining the Cross-Section of Stock Returns in Japan: Factors or Characteristics? In: The Journal of Finance (56), p. 743766.

Lintner, John (1965): The Valuation of Risk Assets and the Selection of Risky Investments in Stock Portfolios and Capital Budgets. In: The Review of Economics and Statistics (47), p. $13-37$.

Mondello, Enzo (2015): Portfoliomanagement. 2. Aufl. Wiesbaden: Springer Fachmedien.

Mossin, Jan (1966): Equilibrium in a Capital Asset Market. In: Econometrica (34), p. 768783.

Newey, Whitney K.;Kenneth D. West (1987), A Simple, Positive Semi-Definite, Heteroskedasticity and Autocorrelation Consistent Covariance Matrix, Econometrica 55 (3), p. 703-08.

Reinganum, Marc R. (1981): A new Empirical Perspective on the CAPM. In: Journal of Financial and Quantitative Analysis (16), p. 439-462.

Rosenberg, Barr; Reid, Kenneth; Lanstein, Ronald (1985): Persuasive evidence of market inefficiency. In: The Journal of Portfolio Management (11), p. 9-16.

Ross, Stephen A. (1976): The Arbitrage Theory of Capital Asset Pricing. In: Journal of Economic Theory (13), p. 341-360.

Said, Said E.; David A. Dickey (1984): Testing for Unit Roots in Autoregressive-Moving Average Models of Unknown Order, Biometrika (71), p. 599-607.

Sharpe, William F. (1964): Capital Asset Prices: A Theory of Market Equilibrium under Conditions of Risk. In: The Journal of Finance (19), p. 425-442.

Stehle, Richard; Schmidt, Martin H. (2015): Returns on German Stocks 1954 to 2013. In: Credit and capitals markets: Kredit und Kapital (48), p. 427-476.

Viale, Ariel M.; Kolari, James W.; Fraser, Donald R. (2009): Common risk factors in bank stocks. In: Journal of Banking \& Finance 33 (3), p. 464-472.

Ziegler, Andreas; Eberts, Elke; Schröder, Michael; Schulz, Anja; Stehle, Richard (2007): Multifaktormodelle zur Erklärung deutscher Aktienrenditen. Eine empirische Analyse. In: $z f b f$ (59), p. 355-389.

Zimmermann, Heinz (Hg.) (2006): Finance Compact. 2. Aufl.: Neue Züricher Zeitung. 